ISSN 1991-8631

Original Paper

http://indexmedicus.afro.who.int

\title{
Weight reducing and hypocholesterolemic effects of aqueous extract of the leaves of Tridax procumbens Linn on sub-chronic salt-loaded rats
}

\author{
Jude Chigozie IKEWUCHI *, Eugene N ONYEIKE, Augustine A. UWAKWE and \\ Catherine Chidinma IKEWUCHI
}

Department of Biochemistry, Faculty of Science, University of Port Harcourt, P.M.B. 5323,

Port Harcourt, Nigeria

"Corresponding author, E-mail: ecoli240733@yahoo.com, Tel: +2348033715662

\begin{abstract}
The effects of aqueous extract of Tridax procumbens on the weight gain and organ weights, plasma lipid profiles and atherogenic indices were studied in sub-chronic salt-loaded Wistar rats. The control group received a diet consisting $100 \%$ of the commercial feed, while the four test groups received a diet consisting $8 \%$ salt and $92 \%$ commercial feed all through, except for the reference treatment group that had its salt-loading discontinued after six weeks. The extract was orally administered daily at 150 and $200 \mathrm{mg} / \mathrm{kg}$ body weight; while the test control, reference and control groups received appropriate volumes of water by the same route. Compared to test control, the treatment produced lower (significantly, $\mathrm{P}<0.05$ ) mean daily weight gain, plasma LDL and non-HDL cholesterol, and (non-significantly) atherogenic indices, plasma triglyceride, total- and VLDL-cholesterol; and higher plasma HDL cholesterol, without significant alterations in organ weights and sizes. These results indicate a likely dose dependent cardio-protective potential of the extract on the hypertensives.

(C) 2011 International Formulae Group. All rights reserved.
\end{abstract}

Key words: Atherogenic indices, plasma lipoprotein cholesterol profile, plasma triglyceride levels, saltloading, Tridax procumbens, weight gain.

\section{INTRODUCTION}

Hypertension, which is characterized by multiple alterations in the structure and function of the cell membrane, is often associated with important metabolic abnormalities including those concerning lipid metabolism. Dyslipidemia accompanying essential hypertension consists of elevated plasma triglycerides, low HDL cholesterol, and increased levels of atherogenic LDL cholesterol particles (Lopes et al., 1997; Zicha et al., 1999). The altered membrane microviscosity seen in hypertensive subjects reflects the changes of membrane lipid composition resulting from intensive exchange between circulating and membrane lipids, as well as from abnormal cellular lipid synthesis and metabolism. Alterations in plasma or membrane lipids are indeed closely associated with ion transport abnormalities as well as with impaired control of cytosolic $\mathrm{Ca}^{2+}$ and $\mathrm{pH}$ in various forms of hypertension in both humans and rats. Such lipid-dependent modifications of membrane properties in cells participating in the cardiovascular regulation might be a part of pathogenetic mechanisms 
responsible for chronic blood pressure elevation (Zicha et al., 1999), as well as alterations in the vascular system leading to vessel damage (Catalano et al., 1991; Bernardes-Silva et al., 1995). Therefore, any nutritional and pharmacological intervention that improves or normalizes abnormal lipid metabolism may be useful for reducing the risk of cardiovascular complications in the hypertensive.

Tridax procumbens Linn (compositae), commonly called coat buttons, tridax daisy, tridax, is widespread in the tropical and subtropical parts of the world (Jahangir, 2001). It is traditionally used in the management of hypertension (Salahdeen et al., 2004). It is rich in saponins (Ikewuchi et al., 2009), a family of compounds that have proven hypocholesterolemic activity (Berhow et al., 2002; Soetan, 2008; European Food and Safety Authority, 2009; Ceyhun Sezgin and Artık, 2010).

Therefore, the present study was designed to investigate the effect of aqueous extract of the leaves of Tridax procumbens on weight gain and organ weights, plasma lipid profiles and atherogenic indices of subchronic salt-loaded Wistar rats, with a view to finding any likely cardio-protective potential of the plant.

\section{MATERIALS AND METHODS}

Collection of animals and preparation of plant extract

Albino rats (of both sexes) were collected from the animal house of the Department of Physiology, University of Nigeria, Enugu Campus, Enugu, Nigeria. Samples of the fresh Tridax procumbens plants were collected from within the Choba and Abuja Campuses of University of Port Harcourt, Port Harcourt, Nigeria. After due identification at the University of Port Harcourt Herbarium, they were washed to rid them of dirt and the leaves were removed, dried and ground into powder. The resultant powder was soaked in boiled distilled water for $12 \mathrm{~h}$, after which the resultant mixture was filtered and the filtrate (herein referred to the aqueous extract) was stored in the refrigerator for subsequent use. A known volume of this extract was evaporated to dryness, and the weight of the residue used to determine the concentration of the filtrate, which was in turn used to determine the dose of administration of the extract to the test animals.

\section{Experimental design}

Studies were conducted in compliance with applicable laws and regulations. The rats were randomly sorted into five groups of five animals each, so that the average weight difference was $\pm 1.5 \mathrm{~g}$. The animals were housed in plastic cages. After a one-week acclimatization period on Guinea growers mash (Port Harcourt Flour Mills, Port Harcourt, Nigeria), the treatment commenced and lasted for seven weeks. The control group received a diet consisting $100 \%$ of the commercial feed, while the four test groups received a diet consisting $8 \%$ salt and $92 \%$ commercial feed. The $8 \%$ dietary salt-loading was adapted from Obiefuna et al. (1991). At the end of the sixth week, the rats were weighed, then fasted overnight and their plasma triglyceride levels were determined (using test strips, with blood from tail cuts), before commencing the administration of the extract; while the reference treatment group had its salt-loading discontinued. The first test group (Test 1) received daily by intra-gastric gavages $150 \mathrm{mg} / \mathrm{kg}$ body weight of the Tridax procumbens extract; the second group (Test 2) received $200 \mathrm{mg} / \mathrm{kg}$ body weight of the Tridax procumbens extract; while the other three groups, test control, reference treatment (reference) and control groups received appropriate volumes of water by the same route. The dosage of administration of the extract was adapted from Bhagwat et al. (2008). Discontinuation of salt-loading was used as the reference treatment. The animals were allowed food and water ad libitum. At the end of the one week treatment period, the rats were weighed, fasted overnight and anaesthetized by exposure to chloroform. 
While under anesthesia, they were painlessly sacrificed and blood was collected (via jugular cut) from each rat into heparin sample bottles. Whole blood was used to determine the triglyceride levels (using test strips), the heparin anti-coagulated blood samples were centrifuged at $1000 \mathrm{~g}$ for $10 \mathrm{~min}$, after which their plasma was collected and stored for subsequent analysis.

\section{Determination of the plasma lipid profiles/indices}

Plasma triglyceride concentration (TG) was determined using multiCarein ${ }^{\mathrm{TM}}$ triglyceride strips and glucometer (Biochemical Systems International, Arezzo, Italy). The test is based on lipase/glycerol kinase/glycerol phosphate oxidase/peroxidase/chromogen reaction. The intensity of the color developed from the reaction is proportional to the concentration of triglycerides in the blood. Plasma total and high density lipoprotein cholesterol (TC and HDLC) concentrations were assayed enzymatically using Randox commercial test kits (Randox Laboratories, Crumlin, England). In the presence of magnesium ions, low density lipoproteins (LDL and VLDL) and chylomicrons fractions are precipitated quantitatively by the addition of phosphotungstic acid. After centrifugation, the cholesterol concentration of the high density lipoprotein (HDL) fraction, which remained in the supernatant, was determined, as in total cholesterol. The cholesterol released by enzymatic hydrolysis is oxidized with the concomitant release of hydrogen peroxide, whose breakdown leads to the conversion of 4-aminoantipyridine to quinoneimine (the indicator) whose concentration can be determined spectrophotometrically at $500 \mathrm{~nm}$. Plasma VLDL- and LDL-cholesterol (LDLC and VLDLC) concentrations were calculated using the Friedewald equation (Friedewald et al., 1972) as follows:

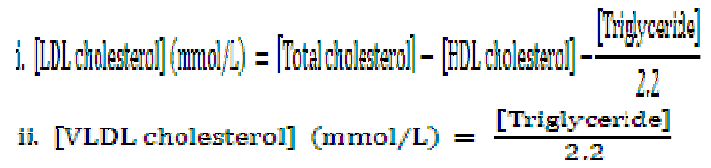

While the plasma non-HDL cholesterol concentration was determined as reported by Brunzell et al. (2008): [Non-HDL cholesterol] $=[$ Total cholesterol $]-[$ HDL cholesterol $]$

The atherogenic indices were calculated as earlier reported by Ikewuchi and Ikewuchi (2009a,b) using the following formulae:

i. Cardiac Risk Ratio (CRR) $=\frac{\text { [Total cholesterol] }}{\text { [HDL cholesterol] }}$

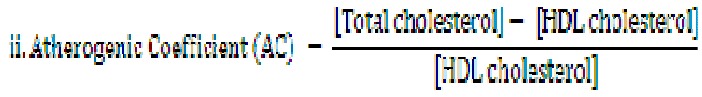

i1. Atherogenic Index of Plasma $(A I P)=\log \frac{[\text { Triglyceride }]}{[\mathrm{HDL} \text { cholesterol] }}$

\section{Determination of organ weights and sizes}

The carcasses of the rats were dissected and their lungs, kidney, heart and liver were collected and weighed. The sizes of the organs were also determined, by water displacement method, using an eureka can.

\section{Statistical analysis of data}

All values are quoted as the mean \pm SEM. The values of the various parameters were analyzed for statistical significant differences between the groups, using the student's t-test, with the help of SPSS Statistics 17.0 package. $\mathrm{P}<0.05$ was considered to be significant.

\section{RESULTS}

The mean daily weight gain and organ weights of the animals are given in Table 1. Before treatment, there was no difference in the mean daily weight gains of all the groups. However, after treatment, Test 2 was significantly $(\mathrm{P}<0.05)$ lower than baseline and test control, but not different from control, reference treatment and Test 1 . There was no significant difference $(\mathrm{P}<0.05)$ in the percentage change in weight gain for all the groups. The heart, kidney, liver and lung sizes of all the groups were not significantly different. The heart weight of Test 1 was significantly $(\mathrm{P}<0.05)$ lower than that of the control, but not different from the other groups. The kidney weight of the test groups 
Table 1: Effects of aqueous extract of the leaves of Tridax procumbens on the body and organ weights of sub-chronic salt loaded rats.

\begin{tabular}{|c|c|c|c|c|c|}
\hline \multirow[t]{2}{*}{ Parameter } & \multicolumn{5}{|c|}{ Magnitude } \\
\hline & Control & Test control & Reference & Test 1 & Test 2 \\
\hline \multicolumn{6}{|c|}{ Mean daily weight gain } \\
\hline BA (g/day) & $0.948 \pm 0.243^{\mathrm{a}}$ & $0.997 \pm 0.064^{\mathrm{a}}$ & $1.309 \pm 0.228^{\mathrm{a}}$ & $0.781 \pm 0.138^{\mathrm{a}}$ & $0.726 \pm 0.171^{\mathrm{a}}$ \\
\hline AA (g/day) & $0.975 \pm 0.820^{\mathrm{a}, \mathrm{b}}$ & $1.081 \pm 0.355^{\mathrm{a}}$ & $1.900 \pm 1.155^{\mathrm{a}, \mathrm{b}}$ & $1.156 \pm 1.348^{\mathrm{a}, \mathrm{b}}$ & $-1.156 \pm 0.577^{\mathrm{b}, \ddagger}$ \\
\hline$\%$ decrease & $0.176 \pm 63.599^{\mathrm{a}}$ & $-0.765 \pm 31.991^{\mathrm{a}}$ & $2.854 \pm 130.464^{\mathrm{a}}$ & $-128.824 \pm 226.939^{\mathrm{a}}$ & $786.953 \pm 610.496^{\mathrm{a}}$ \\
\hline \multicolumn{6}{|l|}{ Heart } \\
\hline Weight (g) & $0.494 \pm 0.037^{\mathrm{a}, \mathrm{c}}$ & $0.392 \pm 0.009^{\mathrm{a}, \mathrm{b}}$ & $0.527 \pm 0.035^{\mathrm{c}, \mathrm{d}}$ & $0.414 \pm 0.031^{\mathrm{b}, \mathrm{d}}$ & $0.503 \pm 0.042^{\mathrm{a}, \mathrm{b}, \mathrm{c}}$ \\
\hline Size $\left(\mathrm{cm}^{3}\right)$ & $0.700 \pm 0.200^{\mathrm{a}}$ & $0.375 \pm 0.025^{\mathrm{a}}$ & $0.475 \pm 0.125^{\mathrm{a}}$ & $0.450 \pm 0.050^{\mathrm{a}}$ & $1.150 \pm 0.350^{\mathrm{a}}$ \\
\hline \multicolumn{6}{|l|}{ Kidney } \\
\hline Weight (g) & $0.842 \pm 0.064^{\mathrm{a}}$ & $0.688 \pm 0.028^{\mathrm{b}}$ & $0.877 \pm 0.067^{\mathrm{a}, \mathrm{b}}$ & $0.822 \pm 0.030^{\mathrm{a}}$ & $0.971 \pm 0.056^{\mathrm{a}}$ \\
\hline Size $\left(\mathrm{cm}^{3}\right)$ & $1.000 \pm 0.100^{\mathrm{a}}$ & $0.650 \pm 0.150^{\mathrm{a}}$ & $0.950 \pm 0.050^{\mathrm{a}}$ & $0.700 \pm 0.100^{\mathrm{a}}$ & $1.550 \pm 0.050^{\mathrm{a}}$ \\
\hline \multicolumn{6}{|l|}{ Liver } \\
\hline Weight (g) & $5.311 \pm 0.310^{\mathrm{a}}$ & $4.830 \pm 0.155^{\mathrm{a}}$ & $5.609 \pm 0.460^{\mathrm{a}}$ & $5.542 \pm 0.459^{\mathrm{a}}$ & $5.543 \pm 0.544^{\mathrm{a}}$ \\
\hline Size $\left(\mathrm{cm}^{3}\right)$ & $3.800 \pm 0.300^{\mathrm{a}}$ & $3.350 \pm 0.350^{\mathrm{a}}$ & $5.800 \pm 0.100^{\mathrm{a}}$ & $5.175 \pm 0.775^{\mathrm{a}}$ & $5.000 \pm 1.500^{\mathrm{a}}$ \\
\hline \multicolumn{6}{|l|}{ Lung } \\
\hline Weight (g) & $1.378 \pm 0.165^{\mathrm{a}}$ & $0.958 \pm 0.078^{\mathrm{b}, \mathrm{c}}$ & $1.324 \pm 0.233^{\mathrm{a}, \mathrm{b}}$ & $0.981 \pm 0.073^{\mathrm{b}}$ & $1.813 \pm 0.283^{\mathrm{a}, \mathrm{c}}$ \\
\hline Size $\left(\mathrm{cm}^{3}\right)$ & $1.975 \pm 0.825^{\mathrm{a}}$ & $0.875 \pm 0.075^{\mathrm{a}}$ & $2.350 \pm 1.250^{\mathrm{a}}$ & $0.850 \pm 0.150^{\mathrm{a}}$ & $3.050 \pm 0.950^{\mathrm{a}}$ \\
\hline
\end{tabular}

were significantly $(\mathrm{P}<0.05)$ higher than the test control, but not the control and the reference treatment. There were no significant differences in the liver weights of all the groups. The liver weight of Test 1 was significantly $(\mathrm{P}<0.05)$ lower than that of Test 2 and control group, but not different from the test control and reference treatment.

The organ weight indices of the animals are given in Table 2 . The heart weight index of Test 1 is significantly $(\mathrm{P}<0.05)$ lower than Test 2, but not significantly different from the control, test control and reference treatment groups. The kidney weight index of the test groups were significantly $(\mathrm{P}<0.05)$ lower than the control and test control but not different from the reference treatment group. The liver weight index of the test groups were significantly $(\mathrm{P}<0.05)$ lower than the control and test control, but not different from the reference treatment group. The lung weight index of Test 2 was significantly $(\mathrm{P}<0.05)$ higher than that of Test 1 and test control, but not different from the control and reference treatment.

The time course of the effects of aqueous extract of Tridax procumbens on the plasma triglyceride levels of salt-loaded rats is given in Table 3. Before treatment, the plasma triglyceride level of Test 1 was significantly $(\mathrm{P}<0.05)$ higher than reference treatment, but not different from control, test control and Test 2. After treatment, there were no significant differences in the plasma triglyceride levels of all the groups. The control group had the most negative change in triglyceride concentration, followed by Test 2 , even though they were not significantly different from all the other groups. The percentage change in plasma triglyceride level of Test 2 was significantly $(\mathrm{P}<0.05)$ higher than the control, but not significantly lower 
than test control, reference treatment and Test 1. Compared to values before treatment, the plasma triglyceride level of control was significantly $(\mathrm{P}<0.05)$ lower.

Table 4 shows the effects of aqueous extract of Tridax procumbens on plasma lipoprotein cholesterol profile and atherogenic indices of salt-loaded rats. The administration of the extract produced a lower (though not significant) plasma total cholesterol concentration in Test 2 compared to control, test control, reference treatment and Test 1 . The administration of the extract produced a higher (though not significant) level of plasma
HDL cholesterol in Test 2 compared to test control, reference treatment and Test 1 , and a lower (though not significant) level than control. There were no significant differences in the plasma VLDL cholesterol levels of all the groups. The plasma LDL and non-HDL cholesterol levels of Test 2 were significantly $(\mathrm{P}<0.05)$ lower than test control, but not different from control, reference treatment and Test 1. All the atherogenic indices of Test 2 were lower (though not significantly), than control, test control, reference treatment and Test 1. These results indicate that the 200 $\mathrm{mg} / \mathrm{kg}$ dose was more effective.

Table 2: Effects of aqueous extract of the leaves of Tridax procumbens on organ weight indices of sub-chronic salt loaded rats.

\begin{tabular}{lccccc}
\hline \multirow{2}{*}{ Parameter } & \multicolumn{5}{c}{ Magnitude } \\
\cline { 2 - 6 } & Control & Test control & Reference & Test 1 & Test 2 \\
\hline HWI & $0.0029 \pm 0.0001^{\mathrm{a}}$ & $0.0029 \pm 0.0001^{\mathrm{a}, \mathrm{b}}$ & $0.0032 \pm 0.0005^{\mathrm{a}, \mathrm{b}}$ & $0.0029 \pm 0.0001^{\mathrm{a}}$ & $0.0033 \pm 0.0001^{\mathrm{b}}$ \\
KWI & $0.0049 \pm 0.0002^{\mathrm{a}}$ & $0.0052 \pm 0.0001^{\mathrm{a}}$ & $0.0053 \pm 0.0010^{\mathrm{a}, \mathrm{b}}$ & $0.0058 \pm 0.0001^{\mathrm{b}}$ & $0.0064 \pm 0.0004^{\mathrm{b}}$ \\
LWI & $0.0310 \pm 0.0008^{\mathrm{a}}$ & $0.0369 \pm 0.0009^{\mathrm{b}}$ & $0.0332 \pm 0.0050^{\mathrm{a}, \mathrm{b}}$ & $0.0386 \pm 0.0021^{\mathrm{b}}$ & $0.0360 \pm 0.0009^{\mathrm{b}}$ \\
LGWI & $0.0081 \pm 0.0011^{\mathrm{a}, \mathrm{b}}$ & $0.0073 \pm 0.0005^{\mathrm{a}}$ & $0.0084 \pm 0.0024^{\mathrm{a}, \mathrm{b}}$ & $0.0069 \pm 0.0006^{\mathrm{a}}$ & $0.0116 \pm 0.0008^{\mathrm{b}}$ \\
\hline Values are mean \pm SD, $\mathrm{n}=5$, per group. Values in the same row with the different superscripts are significantly different at \\
P<0.05. HWI = Heart weight index; KWI = Kidney weight index; LWI = Liver weight index; LGWI = Lung weight index.
\end{tabular}

Table 3: Time course of the effects of aqueous extract of the leaves of Tridax procumbens on the plasma triglyceride levels of sub-chronic salt-loaded rats.

\begin{tabular}{l|c|c|c|c|c}
\hline \multirow{2}{*}{ Parameter } & \multicolumn{5}{|c}{ Magnitude } \\
\cline { 2 - 6 } & Control & Test control & Reference & Test 1 & Test 2 \\
\hline $\begin{array}{l}\text { Before treatment } \\
(\mathrm{mg} / \mathrm{dL})\end{array}$ & $140.967 \pm 15.157^{\mathrm{a}, \mathrm{b}}$ & $113.171 \pm 6.116^{\mathrm{a}, \mathrm{b}}$ & $106.718 \pm 3.014^{\mathrm{a}}$ & $120.120 \pm 2.127^{\mathrm{b}}$ & $115.901 \pm 5.495^{\mathrm{a}, \mathrm{b}}$ \\
After treatment & $112.774 \pm 13.473^{\mathrm{a}, \sharp}$, & $145.435 \pm 24.818^{\mathrm{a}}$ & $142.669 \pm 26.945^{\mathrm{a}}$ & $151.125 \pm 24.109^{\mathrm{a}}$ & $121.361 \pm 12.143^{\mathrm{a}}$ \\
$(\mathrm{mg} / \mathrm{dL})$ & & & & & \\
$\begin{array}{l}\text { Decrease } \\
(\mathrm{mg} / \mathrm{dL})\end{array}$ & & & & \\
$(\%)$ & $28.193 \pm 9.839^{\mathrm{a}}$ & $-32.264 \pm 19.589^{\mathrm{a}}$ & $-35.986 \pm 28.718^{\mathrm{a}}$ & $-31.005 \pm 23.311^{\mathrm{a}}$ & $-5.460 \pm 7.534^{\mathrm{a}}$ \\
\hline
\end{tabular}

Values are mean \pm SEM, $n=5$, per group. Values in the same row with the different superscripts are significantly different at $\mathrm{P}<0.05 ;{ }^{*} \mathrm{P}<0.05$ compared to baseline (before treatment). 
Table 4: Effects of aqueous extract of the leaves of Tridax procumbens on plasma lipoprotein cholesterol profile and atherogenic indices of sub-chronic salt-loaded rats.

\begin{tabular}{lccccc}
\hline Lipid & \multicolumn{5}{c}{ Plasma concentration (mg/dL) } \\
\cline { 2 - 6 } & Control & Test control & Reference & Test 1 & Test 2 \\
\hline Lipoprotein cholesterol & & & & & \\
Total cholesterol & $153.545 \pm 6.371^{\mathrm{a}}$ & $210.055 \pm 25.135^{\mathrm{a}}$ & $174.091 \pm 7.761^{\mathrm{a}}$ & $155.485 \pm 16.216^{\mathrm{a}}$ & $149.742 \pm 9.035^{\mathrm{a}}$ \\
HDL cholesterol & $65.995 \pm 19.073^{\mathrm{a}}$ & $47.690 \pm 3.591^{\mathrm{a}}$ & $55.228 \pm 12.124^{\mathrm{a}}$ & $56.459 \pm 9.228^{\mathrm{a}}$ & $62.920 \pm 12.124^{\mathrm{a}}$ \\
VLDL cholesterol & $22.329 \pm 2.664^{\mathrm{a}}$ & $28.796 \pm 4.903^{\mathrm{a}}$ & $28.255 \pm 5.328^{\mathrm{a}}$ & $29.925 \pm 4.788^{\mathrm{a}}$ & $24.029 \pm 2.394^{\mathrm{a}}$ \\
LDL cholesterol & $65.300 \pm 17.645^{\mathrm{a}, \mathrm{b}}$ & $133.568 \pm 26.602^{\mathrm{a}}$ & $90.608 \pm 8.069^{\mathrm{a}, \mathrm{b}}$ & $69.100 \pm 22.432^{\mathrm{a}, \mathrm{b}}$ & $62.794 \pm 9.112^{\mathrm{b}}$ \\
Non-HDL cholesterol & $87.550 \pm 17.876^{\mathrm{a}, \mathrm{b}}$ & $162.365 \pm 25.251^{\mathrm{a}} 118.863 \pm 9.768^{\mathrm{a}, \mathrm{b}}$ & $99.025 \pm 21.853^{\mathrm{a}, \mathrm{b}}$ & $86.822 \pm 7.413^{\mathrm{b}}$ \\
Atherogenic indices & & & & & \\
Cardiac risk ratio & $3.551 \pm 1.375^{\mathrm{a}}$ & $3.459 \pm 0.689^{\mathrm{a}}$ & $4.057 \pm 0.832^{\mathrm{a}}$ & $3.622 \pm 1.148^{\mathrm{a}}$ & $2.716 \pm 0.367^{\mathrm{a}}$ \\
Atherogenic coefficient & $2.551 \pm 1.375^{\mathrm{a}}$ & $2.459 \pm 0.689^{\mathrm{a}}$ & $3.057 \pm 0.832^{\mathrm{a}}$ & $2.622 \pm 1.148^{\mathrm{a}}$ & $1.716 \pm 0.367^{\mathrm{a}}$ \\
\hline Atherogenic index of & $-0.057 \pm 0.158^{\mathrm{a}}$ & $0.096 \pm 0.107^{\mathrm{a}}$ & $0.078 \pm 0.143^{\mathrm{a}}$ & $0.083 \pm 0.097^{\mathrm{a}}$ & $-0.046 \pm 0.046^{\mathrm{a}}$ \\
plasma & & & & & \\
\hline Values are mean \pm SEM, n=5, per group. Values in the same row with the different superscripts are significantly different at \\
$\begin{array}{l}\text { P<0.05. } \\
\end{array}$
\end{tabular}

\section{DISCUSSION}

Weight reduction is one of the means of alleviating coronary risk incidence, dyslipidemia, hypertension and obesity (Mertens and Van Gaal, 2000; Trussell et al., 2005; Krauss et al., 2006), and is one of the strategies for increasing low HDL-cholesterol levels (NCEP, 2002; Assmann and Gotto, 2004). In this study, the lower mean daily weight gain observed in the test animals may be due to the diuretic effect of saponins present in the leaves (Soetan, 2008). This supports the use of the leaves in the management of hypertension, while suggesting its use in the management of obesity and dyslipidemia; and by extension, the reduction of cardiovascular risk.

Reductions in plasma LDL cholesterol have been considered to reduce risk of coronary heart disease (Rang et al., 2005; Shen, 2007). In this study, we observed a significantly lower plasma LDL cholesterol levels in the animals given $200 \mathrm{mg} / \mathrm{kg}$ body weight, thus indicating the likely cardioprotective effect of the extract at that dose. Many studies have shown that non-HDL cholesterol is a better predictor of cardiovascular disease risk than is LDL cholesterol (Pischon et al., 2005; Brunzell et al., 2008). Therefore, the significantly lower plasma non HDL cholesterol observed in the Test 2 group indicates the ability of the extract (at $200 \mathrm{mg} / \mathrm{kg}$ body weight), to reduce cardiovascular risk. The hypocholesterolemic effect produced by the extracts may be due to its constituent saponins.

Atherogenic indices are strong indicators of the risk of heart disease. The higher their value, the higher the risk of developing cardiovascular complications, and vice versa (Brehm et al., 2004; Dobiásová, 2004; Usoro et al., 2006; Martirosyan et al., 2007). According to Usoro et al. (2006), low atherogenic indices are protective against coronary heart disease. In this study, we observed that the extract, produced lower (though not significantly) cardiac risk ratio, atherogenic coefficient, and atherogenic index of plasma.

\section{Conclusion}

Finally, all of the above results indicate a likely dose dependent protective potential of the extract against the development of atherosclerosis and coronary heart disease, as well as dyslipidemic conditions, whether primary or secondary to hypertension. It also implies that the extract may help manage the dyslipidemic conditions. 


\section{REFERENCES}

Assmann G, Gotto Jr. AM. 2004. HDL Cholesterol and Protective Factors in Atherosclerosis. Circulation, 109(suppl III): III-8-III-14.

Berhow MA, Cantrell CL, Duval SM, Dobbins TA, Mavnes J, Vaughn SF. 2002. Analysis and quantitative determination of group B saponins in processed soybean product. Phytochem. Anal., 13: 343-348.

Bernardes-Silva $\mathrm{H}$, Toffoletto $\mathrm{O}$, Bortolotto LA, Latrilha MCM, Krieger EM, Pileggi F, Maranhão RC. 1995. Malignant hypertension is accompanied by marked alterations in chylomicron metabolism. Hypertension, 26(6): 1207-1210.

Bhagwat DA, Suresh KG, Rahul AS. 2008. Anti-diabetic activity of leaf extract of Tridax procumbens. Intern. J. Green Pharm., 2(2): 126-128.

Brehm A, Pfeiler G, Pacini G, Vierhapper H, Roden M. 2004. Relationship between serum lipoprotein ratios and insulin resistance in obesity. Clin. Chem., 50(12): 2316-2322.

Brunzell JD, Davidson M, Furberg CD, Goldberg RB, Howard BV, Stein JH, Witztum JL. 2008. Lipoprotein management in patients with cardiometabolic risk: Consensus Conference Report From the American Diabetes Association and the American College of Cardiology Foundation. J. Am. Coll. Cardiol., 51(15): 1512-1524.

Catalano M, Aronica A, Carzaniga G, Sergni R, Libretti A. 1991. Serum lipids and lipoproteins in patients with essential hypertension. Atherosclerosis, 87: 17-22.

Ceyhun Sezgin AE, Artık N. 2010. Determination of saponin content in Turkish tahini halvah by using HPLC. Adv. J. Food Sci. Technol., 2(2): 109-115.

Dobiásová M. 2004. Atherogenic index of plasma [log (triglyceride / HDLCholesterol)]: Theoretical and practical implications. Clin. Chem., 50(7): 11131115.
European Food and Safety Authority. 2009. Scientific opinion of the panel on contaminants in the food chain on a request from the European commission on saponins in Madhuca Longifolia L. as undesirable substances in animal feed. The EFSA Journal, 979: 1-36.

Friedewald WT, Levy RI, Friedrickson DS. 1972. Estimation of the concentration of low-density lipoprotein cholesterol in plasma, without use of the preparative ultracentrifuge. Clin. Chem., 18(6): 499502.

Ikewuchi JC, Ikewuchi CC, Igboh MN. 2009. Chemical profile of Tridax procumbens Linn. Pak. J. Nutr., 8(5): 548-550.

Ikewuchi JC, Ikewuchi CC. 2009a. Alteration of plasma lipid profiles and atherogenic indices by Stachytarpheta jamaicensis L. (Vahl). Biokemistri, 21(2): 71-77.

Ikewuchi JC, Ikewuchi CC. 2009b. Alteration of plasma lipid profile and atherogenic indices of cholesterol loaded rats by Tridax Procumbens Linn: Implications for the management of obesity and cardiovascular diseases. Biokemistri, 21(2): 95-99.

Jahangir M. 2001. Chemical and Biological Studies on Some Members of Asteraceae Family and Pseudocalymma elegans, a Native of Brazil. PhD Thesis Submitted to the International Center for Chemical Sciences H.E.J, Research Institute of Chemistry, University of Karachi, Karachi-75270, Pakistan.

Krauss RM, Blanche PJ, Rawlings RS, Fernstrom HS, Williams PT. 2006. Separate effects of reduced carbohydrate intake and weight loss on atherogenic dyslipidemia. Am. J. Clin. Nutr., 83(6): 1025-1031.

Lopes FH, Bernardes Silva H, Soares JA, Filho B, Consolim-Colombo FM, Giorgi DMA, Krieger ME. 1997. Lipid metabolism alterations in normotensive subjects with positive family history of hypertension. Hypertension, 30(3): 629631. 
Martirosyan DM, Miroshnichenko LA, Kulokawa SN, Pogojeva AV, Zoloedov VI. 2007. Amaranth oil application for heart disease and hypertension. Lipids Health Dis., 6: 1.

Mertens IL, Van Gaal LF. 2000. Overweight, obesity, and blood pressure: The Effects of modest weight reduction. Obesity Res., 8(3): $270-278$.

NCEP. 2002. Expert panel on detection, evaluation, and treatment of high blood cholesterol in adults. Third report of the national cholesterol education program (NCEP) Expert Panel on Detection, Evaluation, and Treatment of High Blood Cholesterol in Adults (Adult Treatment Panel III). Final report. Circulation, 106(25): 3143-3421.

Obiefuna PCM, Sofola OA, Ebeigbe AB. 1991. Dietary salt-loading attenuates endothelium dependent relaxation in response to histamine but not to acetylcholine in rat aortic rings. Exptl. Physiol., 76: 135-138.

Pischon T, Girman CJ, Sacks FM, Rifai N, Stampfer MJ, Rimm EB. 2005. Non-high density lipoprotein cholesterol and apolipoprotein $\mathrm{B}$ in the prediction of coronary heart disease in men. Circulation, 112(22): 3375-3383.
Rang HP, Dale MM, Ritter JM, Moore PK. 2005. Pharmacology $\left(5^{\text {th }}\right.$ edn). Elsevier: India.

Salahdeen HM, Yemitan OK, Alada ARA. 2004. Effect of aqueous leaf extract of Tridax procumbens on blood pressure and heart rate in rats. Afr. J. Biomed. Res., 7(1): $27-29$

Shen GX. 2007. Lipid disorders in diabetes mellitus and current management. Curr. Pharmaceut. Anal., 3: 17-24.

Soetan KO. 2008. Pharmacological and other beneficial effects of antinutritional factors in plants - A review. Afr. J. Biotechnol., 7(25): 4713-4721.

Trussell KC, Hinnen D, Gray P, Drake-Nisly SA, Bratcher KM, Ramsey H, Early J. 2005. Case Study: Weight loss leads to cost savings and improvement in metabolic syndrome. Diabetes Spectrum, 18(2): 77-79.

Usoro CAO, Adikwuru CC, Usoro IN, Nsonwu AC. 2006. Lipid profile of postmenopausal women in Calabar, Nigeria. Pak. J. Nutr., 5(1): 79-82.

Zicha J, Kunes J, Devynck MA. 1999. Abnormalities of membrane function and lipid metabolism in hypertension: a review. Am. J. Hypertens., 12(3): 315331. 